\title{
Het onzekere boven het zekere? : onderzoeksvragen rondom assurance services
}

Citation for published version (APA):

Dassen, R. J. M. (1998). Het onzekere boven het zekere? : onderzoeksvragen rondom assurance services. Maastricht University. https://doi.org/10.26481/spe.19981120rd

Document status and date:

Published: 20/11/1998

DOI:

10.26481/spe.19981120rd

Document Version:

Publisher's PDF, also known as Version of record

\section{Please check the document version of this publication:}

- A submitted manuscript is the version of the article upon submission and before peer-review. There can be important differences between the submitted version and the official published version of record.

People interested in the research are advised to contact the author for the final version of the publication, or visit the DOI to the publisher's website.

- The final author version and the galley proof are versions of the publication after peer review.

- The final published version features the final layout of the paper including the volume, issue and page numbers.

Link to publication

\footnotetext{
General rights rights.

- You may freely distribute the URL identifying the publication in the public portal. please follow below link for the End User Agreement:

www.umlib.nl/taverne-license

Take down policy

If you believe that this document breaches copyright please contact us at:

repository@maastrichtuniversity.nl

providing details and we will investigate your claim.
}

Copyright and moral rights for the publications made accessible in the public portal are retained by the authors and/or other copyright owners and it is a condition of accessing publications that users recognise and abide by the legal requirements associated with these

- Users may download and print one copy of any publication from the public portal for the purpose of private study or research.

- You may not further distribute the material or use it for any profit-making activity or commercial gain

If the publication is distributed under the terms of Article $25 \mathrm{fa}$ of the Dutch Copyright Act, indicated by the "Taverne" license above, 


\title{
HET ONZEKERE BOVEN HET ZEKERE? \\ Onderzoeksvragen rondom assurance services
}

\section{Rede}

In verkorte vorm uitgesproken bij de aanvaarding van het ambt van hoogleraar Bedrijfseconomie, in het bijzonder Leer van de Accountantscontrole, aan de Universiteit Maastricht op vrijdag 20 november 1998

\author{
Door
}

Dr. R.J.M. Dassen RA 

Mijnheer de Rector Magnificus, Zeer gewaardeerde toeboorders,

\section{Inleiding}

Het aanvaarden van het ambt van Hoogleraar in de Leer van de Accountantscontrole aan een Faculteit der Economische Wetenschappen \& Bedrijfskunde is niet zonder risico. Voor liefhebbers van spannende romans is dat geen geheim. Zij herinneren zich de passage op bladzijde 126 van Robert Ludlum's onvolprezen 'Het Bourne Bedrog, Roman van een sinistere misleiding', luidend: 'Accountants en economen zijn gezworen vijanden. De ene bekijkt bomen, de andere bossen en bun visies lopen meestal uiteen en zo boort het ook.'x

In mijn rede van hedenmiddag zal ik trachten aan te tonen, dat de heer Ludlum wellicht mooie romans kan schrijven, maar intussen geen benul heeft van de ontwikkelingen in her vakgebied accountancy. Hiertoe zullen wij spreken over de verbreding van de traditionele functie van de accountant - waarin met name onderzoek naar en rapportage over de betrouwbaarheid van financiële (historische) verantwoordingen centraal staat - naar een veelomvattende 'assurance-functie', waarin ook zaken als prognoses, informatiesystemen en organisatiegedrag object van toetsing kunnen zijn. Een ontwikkeling ook, waarin wordt onderkend dat gebruikers van accountantsdiensten soms bereid zijn om het laatste grammetje betrouwbaarheid of nauwkeurigheid in te ruilen voor een grotere relevantie of een betere tijdigheid. De titel van de rede 'Het onzekere boven het zekere?" $\mathrm{kan}$ daarmee op twee wijzen worden geïnterpreteerd. Enerzijds duidt de titel op de hiervoor besproken ontwikkeling, waarbij het primaat van de zekerheid ter discussie wordt gesteld en waarin het mogelijk wordt om betrouwbaarheid en nauwkeurigheid te offeren aan relevantie. ${ }^{3}$ Anderzijds geeft de titel het dilemma aan waarvoor de accountancy-professie zich ziet 
geplaatst: moeten accountants het ruime sop verkiezen van de assurance services - met kansen op het ontdekken van rijke nieuwe gebieden, maar ook met de risico's die de volle zee nu eenmaal inhoudr? Of gaat de voorkeur uit naar hun veilige, maar volgens sommigen toch ook enigszins saaie thuishaven?"4

Het centrale thema in deze rede zullen evenwel niet deze ontwikkelingen sec zijn, maar veeleer de onderzoeksvragen die ermee verband houden. ${ }^{6}$ De onrwikkeling van de traditionele audit/attestation-functie naar de bredere assurance-functie is voornamelijk een aangelegenheid waar beroepsorganisaties en de grotere accountantskantoren actief in opereren. De bijdrage aan de discussie vanuit de academische wereld lijkt in dit verband nog tamelijk bescheiden te zijn. ${ }^{7}$ En dat is jammer. Want er resteren nog fundamentele onderzoeksvragen rondom assurance services. Wie zijn de consumenten voor nieuwe assurance services, en wat zijn hun behoeften? Is sprake van een structurele vraag, of veeleer van een hype? Verliest de jaarrekening - en daarmee het traditionele domein van de accountantsfunctie - werkelijk aan maatschappelijke betekenis? En als de vraag naar deze diensten structureel is, hoe ziet dan de aanbodzijde eruit? Wie zijn de concurrenten voor accountantskantoren? Wat zijn de effecten op de traditionele audit? Hoe moeten voor al die diensten normen worden aangelegd? Wat zijn de gevolgen voor de opleiding, zowel van toetreders tot het vakgebied als van mensen die al jaren actief zijn binnen het traditionele domein van de accountancy?

Teneinde dergelijke vragen in een juist perspectief te kunnen plaatsen, zal eerst aandacht worden gegeven aan de ontwikkelingen die zich voordoen op het gebied van accounting $\&$ accountability, ofwel het afleggen van verantwoording door (de leiding van) ondernemingen aan belanghebbenden. Vervolgens zal worden aangegeven, hoe deze ontwikkelingen van invloed kunnen zijn op de functie en het werkgebied van de accountant. Dit zal de basis vormen voor de inventarisatie van de onderzoeksvragen. 


\section{Verantwoordingsinformatie}

De vraag naar het 'waarom' van het bestaan van verantwoordingsinformatie kan met behulp van de agency-theorie worden beantwoord. ${ }^{9}$ Met behulp van deze theorie kan worden gemodelleerd, hoe externe participanten (bijvoorbeeld aandeelhouders of schuldeisers) in hun hoedanigheid van 'principaal' een bijdrage (bijvoorbeeld in de vorm van vermogen) verlenen aan een onderneming, maar vervolgens mede afhankelijk zijn van de goede wil van het management (als 'agent') om voor deze bijdrage adequat te worden gehonoreerd. Immers, de doelstellingen van agent en principaal kunnen uiteenlopen, zodat de agent de aanwezige (taak)onzekerheid en zijn informatie-voorsprong op de principaal kan benutten om tegenvallende resultaten aan zijn omgeving te wijten en meevallers volledig op zijn eigen rekening bij te schrijven. Principalen zullen deze bron van mogelijke benadeling onderkennen en een hogere vergoeding vragen voor hun bijdrage (in de vorm van een hogere vermogenskostenvoet), of van 'agent' management verlangen dat deze verantwoordingsinformatie verstrekt, waardoor zijn gedrag gevolgd kan worden. ${ }^{10}$ En hier komt de rol van de accountant om de hoek kijken, want principalen zullen meer waarde aan deze informatie toekennen, wanneer zij weten dat deze getoetst is door een objectieve deskundige.

Principalen zullen deze informatie alleen waarderen indien deze regemoet komt aan de eisen die zij hieraan stellen. Teneinde in deze wensen en eisen van de gebruikers van 'business reporting' voldoende inzicht te verwerven, heeft het American Institute of Certified Public Accountants (AICPA) in 199 r het Special Committee on Financial Reporting ingesteld, kortweg het Jenkins Commitree genoemd (AICPA, 1994). Het Jenkins Committee kreeg als opdracht om aanbevelingen te doen over de aard en diepgang waarmee het management informatie zou moeten verstrekken aan derden en over de mate waarin accountants bij deze informatieverschaffing betrokken zouden moeten zijn. Teneinde deze vragen te kunnen beantwoor- 
den, stelde het Committee een uitgebreid onderzoek in naar de wensen van derden" en naar de bereidheid van (het management van) ondernemingen om bepaalde typen informatie te verstrekken. Een belangrijk uitgangspunt woor de studie was het kosten/baten-principe. De baten hebben wij al kort genoemd, een lagere vermogenskostenvoet. Maar wat zijn voor de verschaffer van informatie de belangrijkste kosten? Jenkins kwam tot de onderstaande inventarisatie:

I. Kosten van het produceren en verspreiden van informatie. Deze kosten zijn naar het oordeel van het Committee beperkt, omdat ervan moet worden uitgegaan dat alleen informatie wordt verspreid die ook al ten behoeve van het management is gegenereerd.

2. Kosten van mogelijke aansprakelijkheid als gevolg van het verspreiden van informatie. Gesteld wordt, dat de invloed van uitbreiding van informatieverschaffing op aansprakelijkheid niet eenduidig is vast te stellen. Enerzijds kan additionele informatie aanleiding geven tot meer fouten (zeker indien informatie met een speculatief karakter wordt verlangd). Anderzijds kan additionele informatie juist ter verdediging worden aangewend: hoe meer wordt medegedeeld, des te geringer is de kans dat achteraf met succes schade kan worden geclaimd als gevolg van het achterhouden van informatie.

3. Kosten van het concurrentieel nadeel als gevolg van het verspreiden van informatie. Dit kosten-element wordt vaak als de belangrijkste belemmering gezien van het uitbreiden van verantwoordingsinformatie. ${ }^{12}$ Immers, informatie die aan de kapitaalmarkt wordt verstrekt, kan evenzo op het bureau van de concurrent belanden. Het Committee is evenwel van mening, dat ook deze kostenpost beperkt kan uitvallen, door erop te wijzen dat: (I) concurrentieel gevoelige informatie ook langs andere kanalen kan uitlekken (ex-werknemers, leveranciers en klanten); en (2) het informatievoordeel beide kanten uitwerkt, doordat bedrijven niet alleen informatie verstrekken aan een concurrent, maar anderzijds ook informatie over die concurrent verkrijgen, ervan uitgaande dat die onder een zelfde rapporteringsverplichting valt. 


\section{The ten elements of the committee's model of business reporting}

Financial and non-financial data

- Financial statements and related disciosures

- High-level operating data and performance measurements that management uses to manage the business

Management's analysis of the financial and non-financial data

- Reasons for changes in the financial, operating, and performance-related data and the identity and past effect of key trends

Forward-looking information

- Opportunities and risks, including those resulting from key trends

- Management's plans, including critical success factors

- Comparison of actual business performance to previously disclosed opportunities, risks, and management's plans

Information about management and shareholders

- Director's, management, compensation, major shareholders, and transactions and relationships among related parties

Background about the compan

- Broad objectives and strategies

- Scope and description of business and properties

- Impact of industry structure on the company

Mede op basis van deze kosten-batenanalyse heeft het Committee zijn raamwerk voor 'business reporting' (zie tabel r) ontwikkeld. Het is een modulair raamwerk, waaruit, in de beleving van het Committee, door onderhandelingen tussen ondernemingsleiding en gebruikers een selectie kan worden gemaakt.

Uit het model blijkt, dat gebruikers van 'business reporting' nog steeds groot belang hechten aan de jaarrekening, die binnen het model dan ook als een verplicht onderdeel te boek staat. Echter, tevens is men van oordeel, dat het confectie-product 'jaarrekening' moet (kunnen) worden aangevuld met zaken als prestatiemaatstaven die het management voor interne doeleinden hanteert, diepgaande analyses door het management van ontwikkelingen in te- 
sultaten, prestatiemaatstaven en trends, ${ }^{13}$ prospectieve informatie (met inbegrip van een analyse van risico's en kansen), informatie over management, aandeelhouders en gerelateerde partijen alsmede achtergrondinformatie over de onderneming, waaronder begrepen de doelstellingen en strategie in hoofdlijnen.

\section{Een verbreding van de 'assurance-functie' van de accountant?}

Het Jenkins report besteed took aandacht aan de gevolgen van haar aanbevelingen voor de openbare accountant. De bijdrage van accountants aan de betrouwbaarheid van cijfers in de jaarrekening wordt door $95 \%$ van de respondenten die deelnamen aan de enquête van het Committee onderkend. Ten aanzien van de uitbreiding van het werkterrein van de accountant naar de nieuwe elementen van 'business reporting' is evenwel sprake van verdeeldheid. ${ }^{14}$ Het Committee ziet derhalve zeker mogelijkheden voor een verbreding van de functie van de accountant als beoordelaar van de betrouwbaarheid van elementen van 'business reporting', maar beveelt niet aan om deze inschakeling verplicht te stellen.

In het Jenkins report wordt al melding gemaakt van de oprichting van het AICPA Special Committee on Assurance Services, kortweg het Elliott Committee. Dit Committee kreeg als taak om verslag uit te brengen van zijn analyse van de toekomst van de audit/ assurance-functie, ${ }^{15}$ met als achtergrond (I) de veranderende behoeften van gebruikers van beslissingsondersteunende informatie, zoals onder meer neergelegd in het Jenkins report, alsmede (2) de onderkenning dat de markt voor traditionele jaarrekeningcontroles al jarenlang (in de Verenigde Staten) geen groei meer laat zien.

Het Elliott Committee startte met een analyse van de belangrijkste trends in de omgeving van accountants. Als belangrijkste trend noemt het Committee de ontwikkelingen in de informatietechnologie. Deze zal er volgens Elliott (1994a) toe leiden, dat 'some form of real-time reporting to investors, creditors, and other users 
will be commonplace'. Voor de assurance provider betekent dit, dat de assurance niet meer uitsluitend betrekking zal hebben op de rapportage, maar ook op het informatiesysteem waaruit die rapportage voortvloeit. In een later geschrift beschrijft Elliott (1998) deze ontwikkeling nog stelliger: '... will eventually lead to user access to corporate databases with real-time assurance by 'auditors'. Such access will take the place of periodic paper reports.'

Als tweede hoofdtrend kan men uit het rapport de toenemende maatschappelijke behoefte aan verantwoordingsinformatie afleiden, op gebieden als gezondheidszorg en scholing, maar ook en vooral rondom vermogensverschaffing. In dit kader verwacht het Elliott Committee, dat investeringsstructuren de komende decennia ingrijpend zullen veranderen. Enerzijds zullen pensioenfondsen relaties voor een langere termijn aangaan met ondernemingen waarin zij beleggen, anderzijds zullen particulieren in toenemende mate mede gelet op de Hexibilisering van pensioenen - een eigen verantwoordelijkheid krijgen voor hun beleggingsbeslissingen, vaak met inschakeling van een intermediair.

Mede gelet op deze ontwikkelingen heeft het Elliott Committee een behoefte aan assurance services onderkend, die verder reikt dan het huidige (attestation) domein van accountants en waarin plaats is voor verhoging van zowel betrouwbaarheid als relevantie van informatie. Hiertoe worden assurance services gedefinieerd. (AICPA, I997) als

'... independent professional services that improve the quality of information, or its context, for decision makers. 16

Op basis van deze definitie en het aldus bepaalde speelveld, heeft het Elliott Committee een overzicht gemaakt van enige honderden potentiële assurance services. Van een zestal diensten ${ }^{17}$ is een omvangrijk business plan gemaakt, met daarin een uitwoerige marktanalyse, een overzicht van vaardigheden die nodig zijn om de betreffende diensten te kunnen uitvoeren, een risico-analyse van de 
betreffende diensten en een inventarisatie van gewenste regelgeving.

Op het eerste oog heeft het Elliott Committee zeer zijn best gedaan, vindt U niet? Maar toch mis ik hier de fundamentele onderzoeksaanpak van het Jenkins Committee. Jenkins zocht zeer actief de gebruikers van business reporting op, om hun - veelal latente behoeften in kaart te brengen. Het ware mooi geweest als Elliott op basis van deze inventarisatie zou hebben gebrainstormd over daarbij passende vormen van assurance services en vervolgens daarmee naar diezelfde gebruikers zou zijn gestapt om hun belangstelling voor die diensten te peillen. In plaats daarvan heeft Elliott zich met name gericht op de aanbodzijde. Welke vormen van assurance zijn denkbaar en zien wij al eerste implementaties van bepaalde vormen van assurance bij accountants - en advieskantoren?

\section{Het fundament onder assurance services?}

En zo blijven enkele zeer fundamentele vragen over assurance services onbeantwoord. Vragen ${ }^{\text {r8 }}$ over de

I. Vraagzijde, zoals: wie zijn de consumenten, welke beslissingsprocessen maken zij door, welke informatiebehoeften hebben zij en wat zijn hun behoeften aan assurance-diensten?;

2. Aanbodzijde, zoals: wat is het belang van aansprakelijkheid op assurance services, wat is de invloed van uitvoering van assurance services op de kwaliteit van de jaarrekeningcontrole, wie zijn de aanbieders op deze markt (niet alleen accountants!), welke kostenfuncties kennen zijn en welke (prijs)strategie passen zij toe?; en

3. Toetsingscriteria en technologie, zoals: welke normen, instrumentaria en rapportagestructuren worden gehanteerd bij de beoordeling van de relevantie of betrouwbaarheid van assurance-objecten?

Graag wil ik in deze lezing een aantal van deze fundamentele vra- 
gen met u bespreken. Gegeven de beschikbare tijd zal ik mij in deze lezing beperken tot een selectie van de onderzoeksvragen aan de vraag-en de aanbodzijde. Naar mijn mening zijn inmers de behoefte aan assurance services en de bereidheid om die te leveren verreweg de meest fundamentele kwesties. De ontwikkeling van technologie en normen rondom deze diensten volgt ongetwijfeld, zodra vraag en aanbod elkaar hebben gevonden. Een meer uitvoerige opsomming van onderzoeksvragen treft $u$ overigens aan in het gedrukte exemplaar van deze rede.

Voor de indeling van mijn onderzoeksvragen op de drie genoemde gebieden (vraag, aanbod en technologie/normen) maak ik gebruik van de classificatie van assurance services die is opgenomen in de Exposure Draft 'Reporting on the Credibility of Information' van de International Federation of Accountants (IFAC, 1997), zeer recent omgedoopt tot 'International Standard on Assurance Engagements (IFAC, I998). ${ }^{19}$ Deze indeling luidt als volgt:

- Historische financielle verantwoordingen, ofwel de traditionele core business van accountants;

- Financielle informatie, daaronder begrepen de toetsing van betrouwbaarheid en relevantie van prospectieve informatie;

- Niet-financiële informatie, daaronder begrepen de toetsing van betrouwbaarheid en relevantie van prestatiemeting op basis van kwalitatieve factoren. Maar ook bijwoorbeeld de toetsing van het aantal 'hits' op een internet site, een belangrijk gegeven voor sponsoren van dergelijke sites;

- Systemen en processen, daaronder begrepen de toetsing van de kwaliteit van informatiesystemen, milieuzorgsystemen en interne (risico)beheersingssystemen. ${ }^{20}$ Denkt $u$ in dit verband ook aan de toetsing van organisaties in het kader van Iso-certificering, een relatief grote assurancemarkt die overigens met name door niet-accountants wordt bediend; en

- Gedrag, daaronder begrepen corporate governance en de naleving van gedragsregels (compliance). ${ }^{21}$ 


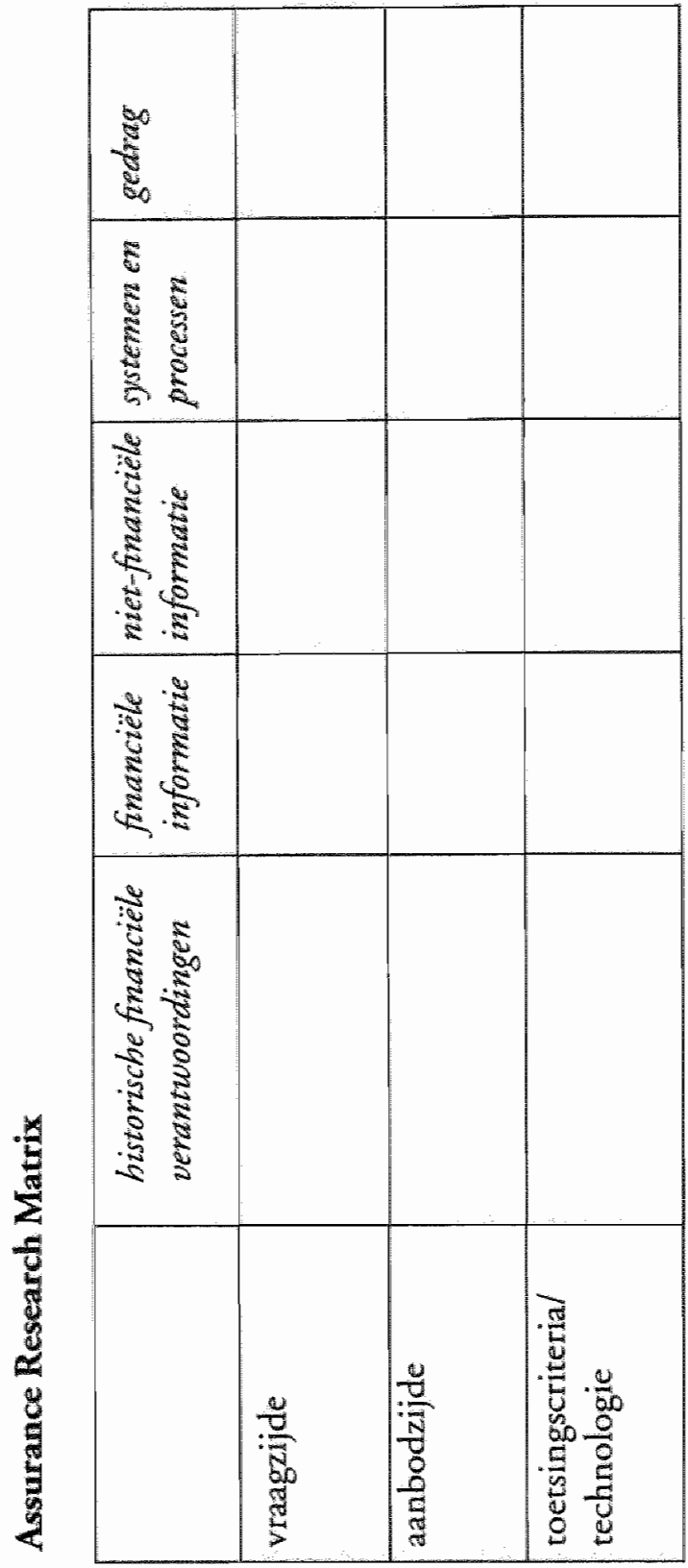


Integratie van deze indeling van assurance services met de onderzoeksgebieden vraag-aanbod toetsingscriteria/technologie leidr tot een assurance research matrix, die kan dienen om de fundamentele onderzoeksvragen op het gebied van assurance services in kaart tebrengen. Zoals gezegd, zal ik mij in deze lezing beperken tot een aantal cellen uit de rijen 'vraag' en 'aanbod'. 22

\section{Vraagzijde}

De meest fundamentele vraag die gesteld kan worden over assurance services is: wie zit erop te wachten en wie is bereid om ervoor te betalen? Uit onderzoek van Brackney \& Helms (1998), See \& Mock (1998) en Dassen \& Schelleman (1998) blijkt, dat accountants de vraag van consumenten naar assurance services als de belangrijkste potentiële hindernis voor de expansie van deze dienstverlening zien. Onderzoek naar deze behoeften is nier eenvoudig. Enerzijds, omdat gebruikers van verantwoordingsinformatie de begrijpelijke neiging hebben om iedere denkbare vorm van additionele informatie te verlangen (zie AICPA, 1994). Anderzijds omdat de uitbreiding van de dienstverlening veeleer het karakter heeft van technology-push dan van demand-pull. Luister in dit kader maar eens naar Robert Elliott (Craig, 1994): '[I]f Thomas Edison had asked users of his day what they wanted, they would have told him they want a candle that burns 24 hours and doesn't smoke or drip. The last thing they would have asked for is an incandescent lamp. Our users also asked for incremental changes. The result is that our ${ }^{23}$ recommendations and model are somewhat conservative.'

Laten wij ondanks deze mogelijke hindernissen de behoefte aan de verschillende vormen van assurance services eens beschouwen. 


\section{Historische financiêle verantwoordingen}

Over het toekomstige maatschappelijke belang van jaarrekeningen - en daaraan gerelateerd: de controle ervan - wordt verschillend gedacht. Waar uit het Jenkins report volgt dat gebruikers de jaarrekening nog altijd als een wezenlijk element in hun informatiebehoeften zien, spreekt Elliott (1995) over 'limited usefulness of today's financial statements'. Lubberink (1998) heeft onderzoek gedaan naar de waarderelevantie van jaarrekeningcijfers van beursgenoteerde Nederlandse ondernemingen over de periode 1983 tot en met 1995. Zijn conclusie luidt, dat de waarderelevantie in Nederland relatief hoog is en over de beschreven periode niet achteruit is gegaan. Ook de recente felle reacties van aandelenbeurzen op winstwaarschuwingen of tegenvallende resultaten doen vermoeden, dat het concept van periodieke financiële rapportage, mits voldoende tijdig, nog een zeer relevante wijze van communicatie met vermogensverschaffers is. Gelet op onderzoeksresultaten, dat de waarderelevantie van jaarrekeningen sterk verschilt per land (Lubberink, 1998) en per bedrijfssector (Lev, I995), zou onderzoek naar de achterliggende oorzaken van deze verschillen van belang kunnen zijn om een behoorlijke inschatting te kunnen maken van het toekomstige maatschappelijke belang van jaarrekeningen en daarmee van jaarrekeningcontroles. Voor Nederland kunnen wij vooralsnog concluderen, dat het doemscenario van Elliott voor de jaarrekening zich nog niet lijkt te voltrekken.

\section{Financielle informatie}

Zoals hiervoor is aangegeven, heeft het Jenkins report behoefte gesignaleerd aan andere vormen van financiële rapportage dan alleen de traditionele jaarrekening. Onderzoek kan aantonen, in hoeverre de verschaffers en de gebruikers van dergelijke informatie 'assurance' wenselij) achten. Bestaand onderzoek op dit terrein (Fargher \& Gramling, 1996 $6^{24}$ en Fargher, Gorman \& Willkins, 1998) ${ }^{25}$ geeft 
aan, dat bij de onderzochte vormen wan vrijwillige prestatiemeting door verschaffers en gebruikers het belang van onafhankelijke assurance wordt onderkend (Fagher \& Gramling, 1996), dan wel dat de door de assurance provider verschafte informatie significant van invloed is op de koersvorming van het aandeel van de onderneming waarop de informatie betrekking heeft (Fargher, Gorman \& Wilkins, 1998). Specifiek onderzoek in deze richting is zeker nog van belang ten aanzien van de gewenste assurance over prospectieve informatie, een categorie die door Jenkins als zeer belangrijk werd aangemerkt en waarin accountants zich tot nu toe slechts bescheiden manifesteren. ${ }^{26}$

\section{Niet-financiële informatie}

Groot (1996) geeft een samenvatting van de internationale literatuur, waaruit blijkt dat traditionele accounting informatie in het kader van de beoordeling van de prestaties beperkingen kent. Met name het ontbreken van relevante aspecten in zowel taakstelling als prestatiemeting, ${ }^{27}$ de nadruk op korte termijnresultaten (bij voorbeeld het vergroten van de winst op korte termijn door op onderhoud te bezuinigen, waardoor evenwel de resultaten op langere termijn in gevaar worden gebracht) en de relatieve eenvoud waarmee accounting informatie is te manipuleren, worden in dit verband genoemd. De ontwikkeling van de Balanced Scorecard (Kaplan \& Norton, 1992), waarmee wordt beoogd een evenwichtige verdeling van prestatiemaatstaven over de aspecten financiën, klant, bedrijfsprocessen en leerprocessen te realiseren, kan in dit perspectief worden gezien. ${ }^{28}$ Voor 54 beursgenoteerde Nederlandse ondernemingen onderzocht Groot (1996) het relatieve aandeel van financièle prestatiemaatstaven ten opzichte van procesgerichte en personele maatstaven, ${ }^{29}$ in de beoordeling door concerncontrollers van de prestaties van productieafdelingen. Hij vond, dat elk van deze categorieën ongeveer een zelfde gewicht in de beoordeling had. Overigens vond hij, dat 'bedrijven die bij de beoordeling en de besturing 
van hun business units vooral de nadruk leggen op financiële indicatoren een hoger rendement [blijken] te behalen'.,

In het verlengde van deze bevindingen liggen talloze onderzoeksvragen. Voor accounting research blijft onderzoek naar de beslissingsrelevantie van niet-financiële prestatiemaatstaven en hun invloed op de kwaliteit van interne en externe besluirvorming zeer relevant, alsmede onderzoek naar de invloed van beschikbaarheid van dergelijke informatie op de vermogenskostenvoet van een onderneming. Voor audit/assurance research liggen er onderzoeksvragen naar de initiele betrouwbaarheid van niet-financiële informarie, ${ }^{31}$ alsmede naar de behoefte van interne en externe besluitvormers aan assurance over de relevantie en betrouwbaarheid van dergelijke informatie.

\section{Systemen en processen}

De behoefte aan assurance over interne beheersingssystemen wordt al enige jaren door accountants aangeduid als een belangrijk assurance-object. Hooton \& Landsittel (1991), zelf partners in een accountants- en adviesorganisatie, stellen in dit verband, dat beleggers uiteindelijk primair zijn geïnteresseerd in de kwestie: is de onderneming "in control", ofwel: heeft het management voldoende greep op de kansen en risico's die zich in en rondom de onderneming voordoen? In het kader van Corporate Governance is aandacht voor dit aspect ruim aan bod geweest, in Nederland cullminerend in een aanbeveling om in het jaarverslag aandacht te besteden aan de hoofdlijnen van strategie, de daaraan verbonden risico's alsmede de belangrijkste elementen van risicobeheersing. ${ }^{32}$ Ten aanzien van een mogelijke rol van de accountant als toetser van dergelijke verantwoordingsinformatie wordt door het Nederlandse bedrijfsleven evenwel terughoudend gereageerd. 3 Anders dan in bij voorbeeld het Verenigd Koninkrijk, waar mede naar aanleiding van het Cadbury Report (Committee on the Financial Aspect of Corporate Governance, 1992) accountants zijn gehouden om - 
voorzichtig ${ }^{34}$ - te rapporteren over het statement van de Board over internal control. Een belangrijke onderzoekswraag op dit terrein is, of "internal control" wordt gehonoreerd door belanghebbenden. Immers, vanuit het perspectief van de informatieverschaffende ondernemingen zal gelden, dat vrijwillige informatieverschaffing over internal control en assurance van een derde daarover alleen dan interessant is, indien dit wordt gehonoreerd in de vorm van een lagere vergoeding (zoals een lagere vermogenskostenvoet). Onderzoek op dit terrein is schaars, de mogelijkheden zijn des te rianter. Gedacht kan worden aan experimentele studies, waarin aan verschillende groepen beslissers uiteenlopende vormen van (assurance over) internal control-informatie wordt verschaft. Of er kan worden gekeken naar reacties van aandelenmarkten op publieke informatie over de kwaliteit van internal control-systemen. ${ }^{35}$

Veel auteurs (Elliott, 1994a; 1998; Percy, 1997) hebben hun verwachting geuit, dat in de toekomst ondernemingen op real-time basis financiële en niet-financiële informatie - bij voorbeeld via het Internet - beschikbaar zullen stellen aan beleggers en dat behoefte zal ontstaan aan real-time assurance services ten aanzien van de inpurgegevens, de processen en de informatiesystemen die deze database voeden. Systematisch onderzoek naar de informatiebehoeften en werkwijzen van financiële analisten, alsmede naar de kosten van informatieverschaffing op deze wijze (zie bij de bespreking van het Jenkins report) is van belang voor de inschatting of deze vorm van informatieverstrekking zich binnen afzienbare tijd zal voordoen. Tevens zal dergelijk onderzoek een indicatie geven van de behoefte aan assurance services die de betrouwbaarheid en relevantie van deze informatie kunnen vergroten.

Assurance services ten aanzien van Electronic Commerce zijn ook door het Elliott Committee als een interessante uitbreiding van het dienstenpakket gezien. Zakendoen voor bedrijven en particulieren via het Internet wordt algemeen als antrekkelijk beschouwd, maar 
de groei ervan wordt beperkt door zorgen over de veiligheid van de afwikkeling van de transactie. Gray $\&$ Debreceny (1998) doen de suggestie om deze zorgen te onderzoeken, gebruik makend van gedragswetenschappelijke technieken, teneinde te identificeren waar de behoefte bestaat aan assurance op dit terrein.

\section{Gedrag}

In diverse landen is op uiteenlopende wijze aandacht besteed aan de rol van de accountant bij toersing van de naleving van de Corporate Governance-regels (zie ook de discussie hierover bij 'internal control'). Onderzoek naar deze verschillen en naar de oorzaken die hieraan ten grondslag liggen, kan nader inzicht verschaffen in de 'drivers' van de behoefte aan dergelijke diensten. Interessant is voorts een artikel in Het Financieele Dagblad van 22 oktober 1998 , waarin melding wordt gemaakt van de screening door de Gemeente Amsterdam van de integriteit van de aannemers waaraan men bouwprojecten wil uitbesteden. Het bericht roept de vraag op, in hoeverre de behoefte aan deze en vergelijkbare vormen van integriteitsbeoordeling ook bij anderen leeft en of hier derhalve sprake zou kunnen zijn van een structurele markt.

Wat leert ons deze verkenning langs de vraagzijde? Allereerst de onderkenning, dat de jaarrekening nog niet dood en begraven is. De relevantie ervan staat in Nederland kennelijk nog niet fundamenteel ter discussie en daarmee is het perspectief van een plaatsje in het museum voor de traditionele accountant nu niet aan de orde. Voorts leert deze verkenning, dat er nog verrassend weinig onderzoek is verricht naar de beslissingsrelevantie van andere verantwoordingsinformatie dan historische, financiële verslaggeving. Duidelijkheid hierover is noodzakelijk om adequate voorspellingen te kunnen doen over de fundamentele vraag naar de behoefte van assurance over deze vormen van informatie. Als ik een subjectieve inschatting zou moeten maken van de mogelijkheden voor assuran- 
ce services, dan dicht ik goede kansen toe aan de assurance over de kwaliteit van informatiesystemen en risicobeheersingssystemen. De mensheid is de laatste jaren verwend door de indrukwekkende snelheid waarmee informatie beschikbaar komt. Uiteindelijk mag je verwachten, dat de roep om continuele informatie in de vorm van een real-time database voor externe analyse-doeleinden in dit licht niet is tegen te houden. Assurance over de genoemde systemen wordt daarmee relevanter dan assurance over de informatie die als output periodiek door dergelijke systemen wordt gegenereerd.

\section{Aanbodzijde}

Maar stel nu dat er inderdaad een grote vraag naar assurance services blijkt te bestaan. Zijn accountants - en adviesorganisaties dan bereid om deze diensten te leveren? Uit onderzoek (Brackney \& Helms, I996; ${ }^{36}$ See \& Mock, 1998; 37 Dassen \& Schelleman, 1998) ${ }^{38}$ blijkteenduidig, dat zij grote belangstelling hebben voor de uitbreiding van hun dienstenpakket naar assurance services. Niet echt verrassend natuurlijk. Het door het Elliott Committee geschilderde perspectief van een extra omzet van vele miljarden dollars is natuurlijk aanlokkelijk. Maar ook als kan worden aangetoond dat er een overtuigende belangstelling aan de vraagzijde bestaat voor assurance services, dan noggeldt dat er aan de aanbodzijde de nodige noten gekraakt moeten worden. Bij onderzoek onder partners en managers in Singapore vonden See \& Mock (I998) in dit verband vooral aansprakelijkheid en gebrek aan kennis als de belangrijkste potentiële hindernissen op de weg naar uitbreiding van assurance services. Het optreden van anderen dan accountants als aanbieders van assurance services werd niet als een belangrijke hindernis ervaren. ${ }^{39}$ Dassen en Schelleman (1998) vonden bij hun onderzoek onder voor vaktechniek verantwoordelijke Nederlandse Big Six partners vooral aansprakelijkheid, bedreiging van onafhankelijk en het effect op de gepercipieerde kwaliteit van de jaarrekeningcontrole alls mogelijke hindernissen. Laten wij deze en andere belemmeringen eens beschouwen vanuit onderzoeksperspectief. 


\section{Generiek}

Welke invloed zal aansprakelijkheid hebben op de aanbieding van assurance services?

Aansprakelijkheid staat duidelijk hoog genoteerd bij accountants als het gaat om mogelijke hindernissen voor het succes van assurance services. Veel accountants vrezen dat bijvoorbeeld assurance ten aanzien van de kwaliteit van het risicobeheersingssysteem binnen een onderneming tot een zeer grote claimgevoeligheid zal leiden in het geval die onderneming korte tijd na die assurance ten onder gaat. Op zich een terechte zorg. Aan de andere kant kan worden beweerd, dat aansprakelijkheid de keerzijde is van relevantie. Ofwel, het is waarschijnlijk, dat aansprakelijkheidsrisico's groter worden naarmate werkzaamheden worden verrichten die voor gebruikers een grotere relevantie hebben. Maar door het schip zorgvuldig buiten de woeste wateren van de aansprakelijkheid te houden, lopen accountants het risico dat zij diensten leveren waaraan uiteindelijk nauwelijks meer behoefte bestaat. De onderzoeksmogelijkheden op dit terrein zijn legio. Carcello et al. (1998) noemen in dit verband mogelijk onderzoek naar de risico-beheersing rondom de acceptatie van assurance-opdrachten, de beperking van de relevantie van assurance services wanneer de assurance provider zijn aansprakelijkheid expliciet afschermt, maar ook onderzoek naar het vermogen van assurance providers om claimgevoeligheid van een bepaalde opdracht te voorspellen.

Hebben de huidige accountants de juiste attitude en de juiste kennis en vaardigheden om deze services te kunnen aanbieden?

Ten aanzien van het aspect attitude zou kunnen worden beargumenteerd, dat assurance services minder gestructureerd zijn dan traditionele audit services en daarmee, in termen van de MyersBriggs Type Indicator (Briggs-Myers \& McCaulley, 1985), eerder passen bij 'intuition' (intuïtief te werk gaande) dan bij 'sensing' (systematisch te werk gaande) types. Immers, voor veel assurance- 
vormen zal gelden, dat het werk minder langs geëffende paden zal verlopen dan het doorgaans zeer gestructureerde proces van controle van de jaarrekening. En bovendien zal de assurance provider flexibel moeten inspelen op de individuele behoeften van de belanghebbenden. Recent onderzoek van Schloemer \& Schloemer (1997) wijst evenwel uit, dat de persoonlijkheidskenmerken van accountants niet gewijzigd zijn ten opzichte van voorgaand onderzoek (Otte, 1983, Kreiser et al., 1990) en nog altijd overwegend van het 'sensing-thinking-judging'-type zijn.40 Toekomstig onderzoek zou kunnen uitwijzen, of assurance providers met een ander dan traditioneel persoonlijkheidsprofiel door gebruikers worden geassocieerd met hogere kwaliteit. De kennis die noodzakelijk is om assurance services te kunnen verlenen, verschilt uiteraard sterk per type dienstverlening. Vergeleken met de traditionele jaarrekeningcontrole, zal de kennis op een aantal gebieden moeten toenemen. Te denken valt aan kennis van besluitvormingsprocessen bij gebruikers van assurance diensten, ${ }^{4 I}$ alsmede actuele kennis op het gebied van informatiemanagement, ${ }^{42}$ administratieve organisatie, 43 informatie- en communicatietechnologie en prestatiemeting. Tevens veronderstelt het merendeel van de assurance services kennis van de sector waarin een bedrijf opereert, die wezenlijk uitstijgt boven de kennis waarover de gemiddelde accountant op dit moment beschikt. Een grondige analyse van het huidige curriculum zal in dit verband noodzakelijk zijn om studenten optimaal in deze vaardigheden te trainen. Flexibiliteit in eindtermen en examinering is naar mijn mening van groot belang om dit ingrijpende veranderingsproces optimaal te faciliteren. Een belangrijk vraagstuk zal voorts zijn, op welke wijze de huidige accountants getraind zullen worden in de hierboven genoemde kennisgebieden. Het belang van een gestructureerd systeem van permanente educatie mag in dit verband niet worden onderschat. 
Welke invloed zal bet uitvoeren van assurance services bebben op de kwaliteitsperceptie van de jaarrekeningcontrole en op de onafhankelijkheid van de accountant die is betrokken bij de controle van de jaarrekeving?

Uit recent onderzoek (See \& Mock; 1998; Dassen \& Schelleman, 1998; Brackney \& Helms, 1998) blijkt, dat met name de grotere accountantskantoren enigszins bezorgd zijn over het effect van assurance services op de maatschappelijke perceptie van de kwaliteit van de controle van de jaarrekening. Ook in de populaire pers is deze mening wel naar voren gebracht, onder meer door te wijzen op het risico dat de kwaliteit van de uitvoering van assurance services niet in lijn zou kunnen zijn met de traditionele hoge standaard van de controle van de jaarrekening, vanwege het minder gestructureerde karakter van de assurancewerkzaamheden en van de rapportage daarover (Berton, 1996).44 Empirisch onderzoek naar de technische en functionele kwaliteit (Dassen, 1995) van assurance dienstverlening kan hier duidelijkheid in brengen. Een ander aspect is de mogelijke invloed van assurance services op de kwaliteit van de controle van de jaarrekening, indien beide vormen van dienstverlening geschieden door dezelfde anbieder. Hiermee betreden wij een onderzoeksgebied, dat qua concept al uitvoerig is betreden. Immers, de invloed van het verstrekken van adviesdiensten op de (perceptie van) kwaliteit van de jaarrekeningcontrole is reeds jaren een dankbaar domein voor audit researchers. 45 Ten aanzien van de vadrdigheid van accountants om onjuistheden in de jaarrekening te ontdekken, mag een positieve invloed van het uitvoeren van assurance services worden verwacht. Door betrokkenheid bij assurance services als risicomanagement, prestatiemeting of de beoordeling van een inrern beheersings- of informatiesysteem, zal de kennis van de accountant over de bedrijfstak, de onderneming en de interne organisatie immers aanzienlijk kunnen toenemen, zodat de kwaliteit van onder meer de risicoanalyse in het kader van de controle van de jaarrekening kan worden bevorderd. $4^{6}$ Voor de onafhankelijkheid van de accountant geldt evenwel, dat synergie-ef- 
fecten ertoe kunnen leiden dat de accountant goedkoper dan anderen zijn controle van de jaarrekening zal kunnen uirvoeren, derhalve relatief meer zal verdienen aan dergelijke opdrachten ('hoge quasi-rents') en daarom beperkt kan worden in zijn onafhankelijkheid ten opzichte van dergelijke cliënten. En bovendien loert hier het spookbeeld van het collisiegevaar. Ofwel het risico, dat een accountant bij de controle van de jaarrekening in zijn objectiviteit wordt gehinderd door het feit, dat tevoren hijzelf of een collega uit dezelfde organisatie een oordeel heeft uitgesproken over de haalbaarheid van een prognose of de kwaliteit van een informatiesysteem. Een ingewikkeld vraagstuk derhalve, met zowel mogelijke plussen als minnen voor de combinatie van controle en assurance. $47 \mathrm{De}$ in Nederland ten tijde van het schrijven van deze regels woedende 'deining' (Crooijmans, 1998) over het voorstel van NIvRA-voorzitter Bindenga om de financiële banden tussen accountants en consultants door te snijden werpt overigens nog de interessante vraag op, of met dit voorstel ook wordt beoogd om controle en assurance te scheiden. Alhoewel hiervoor in de aard evenveel, of even weinig, aanleiding bestaat als voor de scheiding tussen controle en advies, zou een dergelijke splitsing in Nederland frustrerend werken voor de natuurlijke en geleidelijke ontwikkeling van de strikte controlefunctie naar een bredere en flexibelere assurance-functie, zoals die Jenkins en Elliott voor ogen staat.

Wie zijn de (potentiële) aanbieders van (de verschillende vormen van) assurance services en hoe percipieert de markt de relatieve voor-en nadelen van elke anbieder?

Uit het aangehaalde onderzoek naar de mogelijke hindernissen voor de bloei van assurance services blijkt, dat de accountants- en adviesorganisaties zich minder ongerust maken over mogelijke concurrenten op deze nieuwe markt. De vraag is of deze houding terecht is. Voor veel van de nieuwe diensten geldt, dat accountants geen 'natuurlijk monopolie' hebben. Branchespecialisten, financiële analisten, maar ook IT specialisten en software-ontwikkelaars 
kunnen nu of op termijn voor sommige assurance-producten interessante alternatieven aanreiken. Aan potentiéle cliënten van een bepaalde assurance service zou kunnen worden gevraagd, welke typen aanbieders men geschikt zou achten om de betreffende service uit te voeren. Vervolgens kan worden onderzocht; hoe deze potentiële cliënten de vaardigheden en dienstverleningseigenschappen van elk van deze aanbieders percipiëren. Op deze wijze kan inzicht worden verkregen in de uitgangspositie van elke aanbieder in deze nieuwe markten.

Welk effect zal bet aanbieden van assurance services bebben op de opbouw van accountants-en advieskantoren?

Voor een groot aantal assurance services geldt, dat een team gemiddeld genomen meer ervaren zall moeten zijn dan bij de controle van de jaarrekening. Voorts zal gelden, dat de assurancewerkzaamheden een meer multidisciplinaire aanpak zullen vergen, waardoor een grotere diversiteit aan deskundigheden binnen accountants-en adviesorganisaties moet worden verzameld. Tenslotte kan worden beargumenteerd, dat assurance services door hun bredere scope een groter beroep zullen doen op de branchekennis, waardoor wellicht meer branche-specialisatie zal gaan optreden. De invloed hiervan op de opbouw van accountantskantoren in termen van leverage-verhoudingen, beloningsstructuren en carrièrepatronen kan een interessant onderzoeksdomein vormen, evenals de potentiële belangstelling onder studenten van uiteenlopende disciplines voor het assurance-vak.

Hoe luidt de kostenfunctie van de verschillende assurance services? Welke prijsstrategieën zijn denkbaar?

In aanvulling op onderzoek naar de productiefunctie van de jaarrekeningcontrole (zie onder meer O'Keefe et al., 1994) kan onderzoek worden verricht naar de productiefunctie van verschillende vormen van assurance services. Schelleman (1998) heeft een samenvatting gemaakt van de factoren die van invloed zijn op de prijs van 
de controle van de jaarrekening. Afgezien van kostprijsbepalende factoren zijn dat zaken als reputatie (omvang van het kantoor, maar ook specialisatie in een bepaalde bedrijfstak), "low balling' (een lage prijsstelling bij aanvaarding van een continuele opdracht) en het type contract (vaste versus variabele prijsstelling). Voor elk van deze factoren zou het effect op de prijsvorming van assurance services kunnen worden bestudeerd. Een voorbeeld: door het specifieke karakter van assurance services (maatpak in plaats van confectie), mag worden aangenomen dat kennis bij de assurance provider van de onderneming en de bedrijfstak waarin deze opereert, op een hoger niveau moet liggen dan bij de traditionele audit functie van de accountant. Branchespecialisatie zou in dit verband wellicht nog meer gewaardeerd kunnen worden dan bij de controle van een jaarrekening. Cullinan ( 1998 ) vond in dit verband, dat kleinere accountantskantoren significante fee premiums kunnen verdienen bij een bepaald type assurance service, ${ }^{8}$ door zich in een bedrijfstak te specialiseren.

\section{Historische financiële verantwoordingen}

Vraagstukken over de aanbodzijde van de controle van jaarrekeningen zijn talrijk en maken een belangrijk deel uit van het traditionele domein van de audit research. $\mathrm{Zij}$ vallen evenwel buiten de specifieke scope van deze lezing.

\section{Financiële informatie}

Fargher \& Gramling (1996) onderzochten de vraag naar en het aanbod van attestation services ten aanzien van de toetsing van beleggingsperformance-indicatoren van investment managers. Alhoewel toetreding tot deze markt vrij is, blijken toch met name accountants ${ }^{49}$ de werkzaamheden op dit terrein uir te voeren. Onderzoek onder potentiële gebruikers van dit type assurance services zou inzicht kunnen bieden in de gepercipieerde sterke en zwakke 
elementen van de dienstverlening van de verschillende aanbieders. Imago-onderzoek ten aanzien vain accountants-en advieskantoren en toetsing van de uitkomsten hiervan aan her gewenste serviceprofiel voor verschillende assurance-services kan voorts behulpzaam zijn bij het bepalen van de vormen van dienstverlening die zij met voorrang zullen betreden.

Uit het reeds aangehaalde onderzoek van Dassen \& Schelleman (1998) onder de verantwoordelijke partners/directeuren van de Big Six in Nederland blijkt, dat zij nog verdere groei verwachten in het samenstellen en beoordelen van prospectieve informatie. Het zou interessant zijn om te onderzoeken hoe de perceptie is van gebruikers van accountantsdiensten ten aanzien van de kwaliteit van de betrokkenheid van accountants bij prospectieve informatie. Dit vooral vanwege de nogal beperkte rol die accountants onder de huidige regelgeving spelen ten aanzien van de beoordeling van prognoses. ${ }_{2}{ }^{\circ}$

\section{Niet-financiële informatie}

Uit het onderzoek van Dassen en Schelleman (1998) blijkt tevens, dat in Nederland zeer aanzienlijke groei wordt verwacht op het gebied van prestatiemeting. Ondersteuning bij de opstelling van een balanced scorecard wordt als potentieel zeer belangrijk ingeschat, maar ook in studies naar de verbetering van aandeelhouderswaarde en 'best practice benchmarking' wordt aanzienlijke groei verwacht. Onderzoek naar de kennis en de belangstelling van accountants en andere potentiële dienstverleners (management consultants, informatie-analisten) voor technieken en processen op dit gebied zou een indicatie kunnen geven voor de mate waarin accountants geprepareerd zijn on deze vraagstukken met succes te kunnen oppakken.

\section{Systemen en processen}

De grootste groeiverwachting hebben de respondenten in Dassen 
\& Schelleman (1998) ten aanzien van de toetsing van en rapportage over de kwaliteit van het interne beheersingssysteem. Ook de toetsing van milieuverantwoordingen wordt als relatief belangrijk in de nabije toekomst ingeschat. Onderzoek naar de kwaliteitsperceptie van verschillende aanbieders van dergelijke diensten kan inzicht geven in de relatieve concurrentiepositie van accountants- en adviesorganisaties op dit terrein. In dit verband zou men aan gebruikers van verantwoordingsinformatie assurance-rapporten kunnen voorleggen over bij voorbeeld de kwaliteit van het informatiesysteem van een bedrijf, afkomstig van uiteenlopende aanbieders (bij) voorbeeld een accountantskantoor en een IT consultant) en na te gaan welke invloed deze rapporten hebben op de besluitworming van de betreffende gebruiker.

\section{Gedrag}

De toetsing van naleving van contractuele bepalingen zien de respondenten in Dassen \& Schelleman (1998) niet echt zitten. Wel ziet men advisering over naleving van wet- en regelgeving als een interessant domein. Relevant onderzoek in dit kader is wederom de relatieve concurrentiepositie van de mogelijke aanbieders van toetsing van gedrag, waarbij het duidelijk is, dat accountants zeker niet alleen staan in de aanbieding van dergelijke diensten. In het reeds aangehaalde initiatief van de Gemeente Amsterdam om aannemers te screenen op integriteit, vindt screening plaats door Belastingdienst, Openbaar Ministerie en een verzekeringsbedrijf. Ook specialistische fraude-onderzoekers kunnen in dit verband wellicht een rol spelen. Ander onderzoek zou zich kunnen richten op de mogelijke positieve of negatieve synergie van de combinatie van toetsing van gedrag en jaarrekeningcontrole.

\section{Toetsingscriteria/technologie}

Onderzoek naar toetsingscriteria en te hanteren technologie is wel- 
licht in eerste aanleg minder principieel van aard voor de ontwikkeling van assurance services. Immers, zo kan worden beargumenteerd, indien er belangstelling aan zowel de vraag-als de aanbodzijde is voor bepaalde diensten, dan is de verdere ontwikkeling van normen en technologieën een kwestie van allocatie van ontwikkelcapaciteit en overleg binnen de beroepsgroep. Niettemin is voor onderzoekers deze categorie van vragen zeer interessant, omdat het de mogelijkheid biedt orn actief aan de inhoudelijke ontwikkeling van het vakgebied bij te dragen. Welke vragen kunnen in dit verband worden gesteld?

\section{Generiek}

Is een generiek assurance risk model denkbaar, en wat is het belang van materialiteit in assurance services?

IFAC (1998) modelleert het engagement risk van een assurance service in de componenten inherent, control en detection risk, bekend uit de jaarrekeningcontrole. Het is de vraag of deze modellering ook werkt bij assurance services aangaande systemen en processen of gedrag, en of deze indeling ook van toepassing is op diensten waarbij relevantie in plaats van betrouwbaarheid wordt toegevoegd

Carcello et al (x998) stellen vast, dat het materialiteitsconcept in assurance services nog volstrekt niet is uitgekristalliseerd. Als voorbeeld halen zij de rapportage over de kwaliteit van ouderen(gezondheids)zorg aan, waarin een wezenlijk andere materialiteitsbeleving kan bestaan bij de belanghebbenden dan rondom financiële diensten.

\section{Op welke wijze zal rapportage van assurance services plaatsvinden?}

In IFAC (1998) wordt uitvoerig stilgestaan bij de vraag of rapportering over een assurance service zou moeten plaatsvinden in de vorm van een standaardrapportage, of dat een niet-standaardmatige, specifieke rapportage zou moeten plaatsvinden. Voordeel van een standaardrapportage zou kunnen zijn de bijdrage aan de maat- 
schappelijke (h)erkenning van een bepaalde assurance service en daarmee een versnelde 'institutionalisering' daarvan. Aan de andere kant kan een specifieke rapportage wellicht meer inzicht en detail bieden. Onderzoek naar de effecten van uiteenlopende rapportages op de beslissingen en percepties van gebruikers, kan in de keuze tussen deze twee extremen behulpzaam zijn.

Op welke wijze kunnen toetsingscritreria voor assurance services worden ontwikkeld?

Havelka et al. (1998) bespreken een methodologie, waarbij eerst in focus-group interviews met direct betrokkenen criteria worden geïdentificeerd, waarna vervolgens middels enquêtes in grotere kring bij belanghebbenden wordt getoetst of de criteria herkenbaar en volledig zijn. Dit is een veel geziene methode in wetenschappelijk onderzoek, waar deze wordt aangewend voor de validatie van uiteenlopende research-instrumenten. Het in kaart brengen van in wetenschappelijk onderzoek bekende validatiemethoden en toetsing hiervan op uiteenlopende vormen van assurance services kan een aanzienlijke bijdrage leveren aan de ontwikkeling van kwalitatief hoogstaande toetsingscriteria.

\section{Historische financiële verantwoordingen}

Op dit vlak bestaat reeds een omvangrijke onderzoekstraditie, met name in de hoek van de audit judgment research. Voor een overzicht hiervan wordt verwezen naar Mock (1992).

\section{Financiele informatie}

In het Jenkins report is onder meer gewezen op het toenemende belang van prospectieve informatie. De rol van de accountant in het kader van de toetsing van prospectieve informatie varieert in de traditionele omgeving van 'zeer gering' (geldt voor de toetsing van door het management in het jaarverslag weergegeven toekomstver- 
wachtingen) tot "zeer voorzichtig' (geldt voor de zeer terughoudende ${ }^{51}$ rapportages van accountants naar aanleiding van de beoordeling van toekomstgerichte informatie). Een verdergaande assurance ten aanzien van prospectieve informatie zou gebaat zijn bij onderzoek naar criteria die kunnen worden gehanteerd bij de toetsing van de belangrijkste veronderstellingen in een prognose.

\section{Niet-financiële informatie}

Zoals beschreven bij de onderzoeksvragen voor de aanbodzijde, bestaat er grote belangstelling bij de accountants- en adviesorganisaties om mee te werken aan de opstelling of toetsing van de balanced scorecard of andere vormen van prestatiemeting. Onderzoek naar de relevantie van prestatiemaatstaven onder specifieke omstandigheden zal noodzakelijk zijn, om de assurance provider een kader aan te reiken, waaraan hij de geschiktheid van een stelsel prestatiemaatstaven ten behoeve van interne en externe belanghebbenden kan toetsen.

\section{Systemen en processen}

Gebruik makend van de hierboven reeds aangeduide validatietechniek, hebben Havelka et al. (I998) een lijst ontwikkeld met criteria ${ }^{52}$ die van invloed zijn op de betrouwbaarheid en kwaliteit van het ontwerp van informatiesystemen. Verdere toetsing van de geschiktheid van deze lijst om kwaliteitsverschillen tussen bestaande IT ontwerpen te verklaren vormt een interessant onderzoeksdomein, op het snijvlak van theorie en praktijk. 53

Ten behoeve van de toetsing van de effectiviteit van systemen van interne beheersing kan ten dele gebruik worden gemaakt van generieke 'frameworks', zoals in het coso report (Committee of the Sponsoring Organizations of the Treadway Commission, 1992). Onderzoek is evenwel geboden naar de vertaling van dit generieke 
raamwerk naar specifieke situaties. Zo blijkt uit onderzoek (Gupta \& Govindarajan, 1984; Govindarajan \& Gupta, 1985; Govindarajan \& Fisher, 1990), dat de effectiviteit van een specifiek internal control systeem sterk afhankelijk is van de gekozen ondernemingsstrategie. Onderzoek naar de effectiviteit van beheersingssystemen onder uiteenlopende omstandigheden, alsmede naar de professionele oordeelsvorming die wordt gehanteerd bij de bepaling wanneer niet langer sprake is van een adequaat beheersingssysteem, is noodzakelijk om tot een aanvaardbare normenset voor dit type assurance-services te geraken.

\section{Gedrag}

In het voorgaande is reeds enige malen gesproken over de mogelijke rol van de accountants als toezichthouder op de naleving van corporate governance-voorschriften. Regelmatig is in deze discussie naar voren gekomen, dat een dergelijke rol alleen zinvol is voor toetsbare 'statements'. Voor Nederlandse onderzoekers zou dit kunnen betekenen, dat men nagaat welke van de 40 aanbevelingen $^{54}$ van de Commissie Peters zich in beginsel lenen voor toetsing, en voor welke hiervan al objectieve toetsingskaders bestaan. Voor zover deze nog niet bestaan, kan worden getracht om aan de hand van hierboven beschreven werkwijzen alsnog tot dergelijke normen te geraken.

\section{Samenvatting}

Dames en heren, de afgelopen minuten heeft u een reisje in de roekomst van het vakgebied accountancy mogen meernaken. Toegegeven, het heeft u niet de kreten van ontzetting ontlokt die een spannende Jules Verne teweeg kan brengen. Jaarrekeningen en risk management systemen spreken helaas wat minder tot de verbeelding dan oceaanmonsters en wezens in het heelal. Niettemin hoop ik u te hebben kunnen overtuigen van het feit, dat er in dit vakge- 
bied heel wat staat te gebeuren. En bovenal hoop ik de boodschap over te hebben kunnen brengen, dat praktijk en onderzoek elkaar wat meer aandacht verschuldigd zijn. De kantoren zouden meer naar researchers moeten luisteren om antwoord te krijgen op de fundamentele vragen die gesteld kunnen worden over het succes van assurance services. Want conclusies over een kwijnende belangstelling voor jaarrekeningen en een groot enthousiasme voor assurance services lijken hier en daar te snel te worden getrokken. En, aan de andere kant, researchers zouden de ontwikkelingen die zich voordoen met wat meer enthousiasme mogen oppakken. Het onderzoek op het gebied van assurance services en de ogenschijnlijke academische belangstelling hiervoor is mager, terwijl de mogelijkheden om constructief bij te dragen aan het in goede banen leiden van deze belangwekkende ontwikkeling binnen het vakgebied riant zijn. En tenslotte ligt er natuurlijk nog de forse taak, om het onderwijscurriculum an te passen aan de specifieke eisen die de nieuwe assurance services stellen. Ik beschouw het dan ook als een voorrecht en een uitdaging, om de functie van onderzoeker, docent en praktijkman op het vakgebied 'accountancy' te mogen combineren en langs die weg een bijdrage te mogen leveren aan het slaan van de bruggen tussen deze drie invalshoeken.

\section{Dankwoord}

Daarmee zijn wij aanbeland bij het dankwoord. Laat ik beginnen met de collega's van de sectie Berichtgeving aan deze Universiteit te bedanken. Hun positief-kritische instelling ten opzichte van het vakgebied vormt een geweldig klankbord, waardoor mijn benadering van onderzoek, onderwijs en praktijk voortdurend scherp wordt gehouden. Bovendien doen zij er alles aan, om het ongelijk van Robert Ludlum te bewijzen. Van deze getalenteerde groep economen gaat geen vijandschap, maar juist oprechte vriendschap uit. Een tweede groep van mensen die ik oprechte dank verschuldigd ben, zijn mijn collega's van Deloitte \& Touche. Zij bieden mij ruim- 
te en een enthousiast draagvlak om een aanzienlijk gedeelte van mijn tijd te wijden aan academische bezigheden. Maar ik ben ook specifieke dank verschuldigd aan een aantal individuen. Aan Ton Versteegh en Jan van de Poel, die mijn eerste stappen op het academische pad hebben voorgeprogrammeerd. Aan Arnold Schilder, mijn voorganger in dit ambt, van wie wij vandaag afscheid hebben genomen met een seminar dat is gewijd aan zijn nieuwe, zeer eervolle uitdaging. Hij is niet alleen mijn leermeester en promotor binnen dit vakgebied geweest, maar heeft mij ook op vele andere gebieden wijze levenslessen bijgebracht, en zal dat hoop ik nog geruime tijd blijven doen... Aan Steven Maijoor, die mij het ware onderzoeken heeft bijgebracht en met wie ik vele bomen binnen en buiten het vakgebied heb mogen en nog dagelijks mag opzetten. Willem Buijink, wiens encyclopedische kennis over onderzoek voor mij een onmisbare houvast vormt op de onstuimige research-zee. Tjeu Blommaert, die mij eerst debet van credit leerde onderscheiden, en daar vervolgens onvermoeibaar trebit aan toevoegde... Niet te vergeten onze emeritus Bram Beek, wiens wijze en niet aflatende raadgevingen nog immer in dank worden aanvaard. En Jacques Koenen, onder wiens bezielende dagelijkse leiding een enthousiast en goed docententeam voor de postdoctorale accountancy-opleiding fungeert. Dank ook aan Harold Hassink en ons gewaardeerde secretariaat, Sabine Galama en Miranda Schoep, bakens van rust en orde in de dagelijkse gang van zaken rondom de opleiding en ook van onschatbare waarde voor de gang van zaken vandaag.

In de persoonlijke sfeer aan mijn ouders, die al sinds lang een stimulans vormen voor het vinden van een goed evenwicht tussen maatschappelijk succes en persoonlijke harmonie. En last but not least mijn Petra, die mij liet weten geen prijs te stellen op overdreven dankbetuigingen, maar al tevreden te zijn met de mededeling dat zij onmisbaar is. Een stelling waarover ik graag en zonder aarzeling maximale assurance geef.

Ik heb gezegd. 


\section{LITERATUUR}

American Instïrute of Certified Public Accountants, Statement on Standards for Attestation Engagement No. I-Attestation Standards, New York, 1993

American Institute of Certified Public Accountants, Improving Business Reporting - A Customer Focus: Repart of the Special Committee on Financial Reporting. 1994

American Institute of Certified Public Accountants, Report of the Special Committee on Assurance Services, http:/wwwaicpanorglassurance/index.htm, 1997

Applegate, L.M., McFarlan, F.W., McKenney, I.L., Corporate Information Systhens Management, Text and Cases, $4^{\text {th }}$ Edition, Irwin, 1996

Berton, L., Accountants Expand Scope of Audit Work, The Wall Street Joumal, 17 June 1996

Bindenga, A.J., in: De Rol wan de Accountant, Nu en in de Toekomst, Redactie Maandblad voor Accountancy en Bedrijfseconomie, Elsevier, Den. Haag, I998, p. $18-28$

Blommaert, A.M.M., Addizional Disclosure; Triple-Entry en Momentum Accounting, Stenfert Kroese, Houten, 1994

Brackney, K.S., Helms, G.L., A Survey of Atrestation Practices, Auditing, A Journal of Practice and Theory, Fall 1996

Brackney, K.S., Helms, G.L., Attestation Services: Opportunity for Practice Growth, The CPA Joumal, February 1998

Blokdijk, J.H., De Twee Zijden van de Markr voor Assurance, in: Diekman, P.A.M., Gelderloos, J.O., Verhoog, W., (red.), Assurance of Control; Besturen en Accountancy op Weg natr de zre Eeuw, Kluwer Bedrijfswetenschappen, 1996

Botosan. C., Disclosure Level and the Cost of Equity Capital, The Accotnting Review July 1997

Brecht, H.D., Martin, M.P., Accounting Information Systems: The Challenge of Extending their Scope to Business and Information Strategy. Accounting Horizons, December 1996 
Briggs-Myers, I., McCaulley, M.H., Matmat: A Guide to the Development and Use of the Myers-Briggs Type Indicator, Palo Alto, Consulting Psychologists Press, Inc., 1985

Bryan, S.H., Incremental Information Content of Required Disclosures Contained in Management Discussion and Analysis, The Accownting Review, April 1997

Canadian Institute of Charrered Accountants, Repont of the Inter-Institute Vision Task Force, hrop:/www, cica,ca/new/vision/e vision, htm, 1996

Carcello, J.V., Messier, W.E, Ricchiute, D.N., Research Opportunties in Assurance Services, unpublished paper, 1998

Commissie Peters, Corporate Governance in Nederland, 1997

Committee on the Financial Aspects of Corporate Governance, Report of the Committee on the Financial Aspects of Corporate Governance (Cadbury Report), London, 1992

Committee of the Sponsoring Organizations of the Treadway Commission, Internal Control Integrated Framework (coso Report), New York, 1992

Conover, T.L., Wallace, W.A., Equity Market Benefits to Divclosure of Geogntphic Segment Information: An Argument for Decneased Uncertainty, Working Paper, 1994

Craig, J.L.. Jr., Fïrst Financial Reporting, now the Audit Function; Robert Elliot, Leading the Profession, The CPA Journal, October 1994.

Crooijmans, H., Accountants Bakkeleien, Elsevier, ro oktober 1998

Cuilinan, C.P., Evidence of Non-Big 6 Market Specialization and Pricing Power in a Niche Assurance Service Market, Paper Bryant College, Smithfield, February 1998

Dassen, R.J.M., De Leer van her Gewekte Vertrouneen: Agency avant la lettre?, Maandblad voor Accountancy en Bedrijfieconomie, september 1989

Dassen, R.J.M., Audit Quality: An Empirical Study of the Atributes and Determinants of Audt Quality Perceptions, Doctoral thesis, University of Maastricht, 1995 
Dassen, R. M. en Coster, A.J., in: De Rol van de Accountatu, Nu en in de Toekomst Redactie Maandblad woor Accountancy en Bedrijfseconomie, Elsevier, Den Flagg, 1998, p. $75-82$

Dassen, R.J.M. en Maijoor, S.J., Assurance Services: A European Perspective, Unpublished Paper, 1998

Dassen, R.J.M. en Schelleman, C., The Market for Asswrance Services in the Netherlands, Paper (forthcoming), University of Maastricht, 1998

Davis, L.R., Ricchiute, D.N., Trompeter, G., Audit Effort, Audit Fees, and the Proviston of Nonaudit Services to Audit Clients, The Accowning Review, January 1993

Dhaliwal, D.S., The Impact of Disclosure Regulations on the Cost of Capital, in Economic Consequences of Finawicial Accownting Standards, Stamford, 1978

Elliott, R.K., Confronting the Future: Choices for the Attest Function, Accounting Horizons, September 1994a

Elliotr, R.K., The Furure of Audits, Journal of Accountancy, September $1994 b$

Elliotr, R.K., The Future of Assurance Services: Implications for Academia, Accounting Horizons, December 1995

Elliott, R.K., Assurance Service Opportunities: Implications for Academia, A6counting Florizons. December 1997

Elliotr, R.K., Assurance Services and the Audit Heritage, Lecture at the Waterloo Assurance Services Research Symposium, March 271998

Elliotr, R.K., Pallais, D.N., Are you Ready for New Assurance Services, Joumal of Accountancys June $1997 \mathrm{a}$

Ellion, R.K., Pallais, D.N., First: Know Your Market, Journal of Accountancy, July $1997 \mathrm{~b}$

Elliott, R.K., Pallais, D.N., Büld on Your Firmis Strengths, Journal of Accovintancy August $1997 \mathrm{C}$

Elliott, R.K., Pallais, D.N., To Market, To Market We Go, Journal of Accountanos Seprember r997d 
Fargher ${ }_{2}$ N.L., Gorman, L.R, Wilkins, M.S., Timely Industry Iofomation as aw Assurance Service-Evidence on the Information Content of the Book-bo-Bull Ratio, Paper, University of Oregon, February 1998

Fargher, N.L., Gramling, A.A., A New Market for Artestation Services: The Performance Presentation Standards of the Association for Investment Management and Research, Anditing: A Joumal of Practice and Theory, Supplement 1996

Govindarajan, V., Fisher, J., Strategy, Control Systems, and Resource Sharing: Effects on Business-Unit Performance, Academy of Managewent foumal, Vol. 33, No. 2, 1990

Govindarajan, V., Gupta, A.K., Linking Control Systems to Business Unit Straregy: Impact on Performance, Accounting, Organizations and Society Vol. 1o, No. I, 1985

Gray, G.L., Debreceny, R, Electronic Commerce Aswmance Serwices and Accoun ting Information Systems: A Review of Research Opportunities, Paper, 1998

Groot, T.L.C.M., Sturen op Prestaties; De Rol wan Accounting Informatip in de Bedrijfsoering van Ongamisaties, Wolters-Noordhoff, Groningen, 1996

Groot, T.L.C.M., Van der Meer-Kooistra, J., Wouters, M... F., Dynamiek en Dilernma's rond Prestatiemeting, Tijdschrift voor Bedrifsadministratie, oktober 1998

Gupta, A.K., Govindarajan, V., Business Unit Strategy, Managerial Characteristics, and Business Unit Effectiveness at Strategy Implementation, Academy of Management jourmal, Vol. 2, No. I, 1984

Havelka, D., Sutton, S.G., Arnold, V., A Methodology for Developing Measurement Criteria for Assurance Services; An Application in Information Systems Asstrance, Paper, Thomas More College, 1998

Holstrum; G., in: "The CPA Journal Symposium on the Future of Assurance Services", The CPA Journal, May 1996

Hooton, J.G., Landsittel, D.L., Addressing "Early Warning" and the Public Interest: Auditor Involvement with Internal Control, The CPA Journal, June 1991

Institute of Chartered Accountants in England and Wales, Added-ualue Professionals; Chartered Accountants in 2005, htep//icaew.co.uk/depts/adm/admpolcol2005int.him, 1996 
International Federation of Accountants, Reporting on the Credibility of Information, Exposwe Drafit, 1997

International Federation of Accountants, International Standard on Assurance Engagements, 1998

Kaplan, R.S., Norton, D.P, The Balanced Scorecard - Measures that Drive Performance, Harvard Business Review, Jan/Febr. 1992

King, R.R, Schwartz; R, Planning Assurance Services, Unpublished paper, Washington University, St. Louis, 1998

Kinney, B., Information Assurance and Control for Management Decision Making, Irwin/MoGraw-Hill, 1999

Koninklijk Nederlands Instituut van Registeraccountants, Richtlijnen voor de Accountantscontrole, Amsterdam, 1998

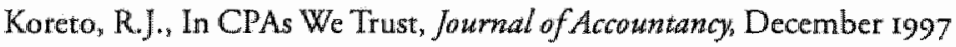

Kreiser L., McKeon, Jr., J.M., and Post, $A_{* x}$ A Personaliry Profile of CPAs in Public Practice, The Ohio CPA Joumal, Winter 1990

Lang, M.H., Lundholm, R.J., Corporate Disclosure Policy and Analyst Behavior, The Accounting Rewiew, October 1996

Lev, B., The Boundaries of Financial Reporting and How to Extend Them, Working paper, University of California at Berkeley, 1995

Lubberink, M.J.P., De Warderelevantie van Jaarrekeninggegevens in de Periode 1983-1995. Tijdschrifi woor Bedrijfsadministratie, januari 1998

Ludlum, R. Het Bourne Bedrog, Roman van een sinistere misleiding, LuitinghSijchoff, 198 r.

Maijoor" S.J. Dowinees op de Markt" Een Economische Analyse van de Markt, bet Kantoor en bet Controleproces wan Accountants, Inaugurale Rede Universitcit Masstricht; 1995

Maisel, L.S., Performance Measurement: The Balanced Scorecard Approach, Joushal of Cost Manatgement, Summer 1992

Maljers, F.A., Assurance en Control: tussen Rekenkunde en Metafysica, naar een 
Nieuw Evenwicht, in: Diekman, P.A.M., Gelderloos, J.O., Verhoog, W., (red.),

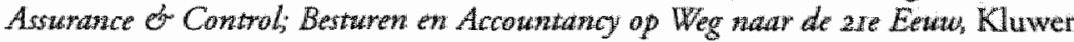
Bedrijfswetenschappen, 1996

Merchant, K.A, Control in Business Organizdtions, Ballinger, New York 1995

Merchant, K.A., Management Contnd Systems: Text and Cases, Prentice-Hall, New York, 1997

Mock, Th..I., Anditing research, Inaugurale rede Rijksuniversiteit Limburg, 1992

Moerland, P.W., Corporate Governance en de Vermogenskostenvoet van de Onderneming, Madndblad woor Accountancy en Bedriffeconomie, maart 1998

O'Keefe, T.B., Simunic, D.A., Stein, M.T., The Production of Audit Services: Evidence from a Major Public Accounting Firm, Journal of Accounting Research, Autumn 1994

Otte, P.J. Psychological Typology of the Local Firm Certified Public Accountant Unpublished doctoral thesis, Western Michigan Universiry, 1983

Palmrose, Z.V., The Effect of Nanandit Services on the Pricing of Audit Services: Further Evidence, Journal of Accownting Research, Autumn 1986

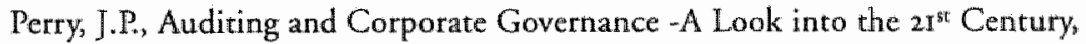
International Joumal of Auditing, February 1997

Schelleman, C., Prior Reseach on Audit Pricing and Audit Production, Paper, Universiteit Maastricht, 1998

Schilder, A., Onderzoekt alles..., Inaugurale rede Rijksuniversiteit Limburg, Wolters-Noordhoff, Groningen, 1989

Schilder A., Auditor Independence: A Real Issue?, Business Ethics, A European Review, October 1992

Schlloemer, P.G., Schloemer, M.S., The Personality Types and Preferences of CPA Firm Professionals: An Analysis of Changes in the Profession, Accounting Horizons, December 1997

See, C., Mock, T.J., The Market for Assurance Services in Singapore, unpublished paper, 1998 
Simunic, D.A., Auditing, Consulting and Auditor Independience, foumal of $A C$ cownting Research, Aurumn 1984

Slagter, W.J., Legal Audit en Compliance Audit (Jaarrekening, Controle en de Wet), in: Diekman, P.A.M., Gelderloos, ]. O., Verhoog, W., (red.), Assurance of Control; Besturen en Accountancy op Weg naar de are Eequ, Kluwer Bedrijfswerenschappen; 1996

Ten Wolde, J., in: De Rol van de Accountant, Nu en in de Toekomist Redactie Maandblad voor Accountancy en Bedriffeconomie, Elsevier, Den Haag, 1998, p. $29-38$

Touw, A.L. Compliance en de Nederlandsche Bank, Voordracht rijdens het KPMG seminar Compliance, 23 juni 1994

Uzumeri, M.V., Tabor, R.H., Emerging Management Metastandards: Opportunities for Expanded Attest Services, Accounting Horizons, March 1997

Vaassen, E.H.J., Objecten en Subjecten van AO-Onderzoek, Oratie Universiteit van Amsterdam, Vossiuspers AUP, 1998

Waardenburg, J., Control A Awdit, Inaugurale rede Vrije Universiteit te Amsterdam, 1997 


\section{EINDNOTEN}

'Maljers (1996, p. 20) voorziet dat het bomen-bos-dilemma in de toekomst alleen nog maar erger wordt, alls gevolg van de mogelijkheden die de informatietechnologie ons biedt. "Vroeger hadden wij het al moeilijk genoeg on door de bomen het bos te kunnen zien. Tegenwoordig kunnen wij niet alleen de bomen zien. De takken, de bladeren en zelfs de nerven op de bladeren kunnen wij goed onderscheiden. En dat maakt het steeds moeilijker ons op het bos te concentreren.'

2Neerlandici zullen bezwaar maken tegen het woord 'bowen', waar het originele spreekwoord luidt: 'het zekere voor het onzekere nemen'. Evernwel wordt in toenemende mare de uitdrukking 'het zekere boven her onzekere verkiezen' gebezigd. Voor deze rede wordt de voorkeur aan deze laatste variant gegeven. Immers, "voor' suggereert de exclusieve keuze van een alternatief, met uitshiting van elk ander, terwijl 'boven' een relatieve voorkeur aangeeft, zonder noodzakelijke uitsluiting van een der alternatieven. Aangezien in assurance services het element zekerheid (betrouwbaarheid) vrijwel altijd in enige worm aanwezig zal zijn - dan dominant, dan in een meer ondergeschikte rol - geeft het relatieve karakter van 'boven' her dilemma zuiverder weer.

${ }^{3}$ Her Elliott Committee merkt hierover op: "An assurance service can add confdence about reliability, relevance, or a combination of them. In some cases, reliability may be sacrificed for relevance (recognizing that some will argue that data that are unreliable cannot be relevant)' (AICPA, 1996).

4 Tekenend woor de dynamiek van deze ontwikkeling is een uitspraak van Colin Sharman, eerste man van de wereldwijde KPMG-organisatie, in her International Accounting Bulletin (20 October 1997), waarin hij de volgende kernachtige uitspraken neerzet:

- het beroep dreigt in de vergetelheid te geraken, tenzij het snel reageert op veranderingen in de omgeving.

- een compleet nieuwe omgeving zal voor accountants ontstaan binnen rooo dagen.

- binnen 5 tot to jaar zal de marke voor accountantsdiensten to sterk zijn veranderd dat deze onherkenbaar zal zijn vanuit het huidige perspectief. Het zal een markt zijn, niet gebaseerd op traditionele verslaggeving, maat op 'information assurance' en 'risk', waarbij kennis van de 'business' en de 'ind.ustry' essentieel zal zijn.

s Hiertoe wordt onder meer verwezen naar de inaugurale rede van Waardenburg $(1997)$. 
${ }^{6}$ Daarmee past deze rede in de (korte) traditie van inaugurale redes op dit vakgebied aan de Universiteit Maastricht, waarbij onderzoek steeds nadrukkelijk op de voorgrond heft gestaan, zie Schilder (1988), Mock (1992) en Maijoor (1995).

Holstrum (1996, p. 23) stelt hierover in een beschouwing over de ontwikkeling van assurance services: "What is the role of academic research in helping to move the profession forward? Academics should be on the leading edge, but often find themselves falling behind with the pace of change."

Zie bijvoorbeeld Blokdijk (1996). Deze stelt (p. 76): "retrospectieve cijfers zijn zeer relevant, want de beurs reageert er kennelijk sterk op (...) Cijfers over het recente verleden zeggen dus veel ower de nabije toekomst (...) Wie zit er te wachten op accountants die "assurance" geven over allerlei informatiesystemen (...) Kortom, thet accountantsheroep moet hiervan niet te snel iets verwachten, want het is maar zeer de vraag of er een markt voor deze 'assurance' is."

9 Zie voor een samenvatting van de agency-theorie op het gebied van verantwoordingsinformatie in de Nederlandse liceratuur onder meer Dassen ( 1989 ), Schilder (1989) en Moerland (1998).

ro Voor de samenhang tussen de vermogenskostenvoet en het verstrekken wan (vetantwoordings) informatie wordt verwezen naat Botosan (1997). In een empirisch onderzoek vond $z i j$, dat de kostenvoet van eigen vermogen significant negatief correleert met de mate van aanvullende toelichting. Zie voor vergelijkbare onderzoeken en bevindingen Dhaliwal (r978) en Conover \& Wallace (1994). Lang $\&$ Lundholm (1996) vonden in een empirische studie, dat bedrijven die meer informatie verschaffen: (1) meer worden gevolgd door analisten; en ( $z$ ) een accuratere en consistentere voorspelling door analisten kennen. Schattingsrisico's en informatie-asymmetrie zijn voor dergelijke bedrijwen derhalve beperkter, zodat de vermogenskostenvoet waarschijnlijk lager ligt.

"Herbij oriènteerde men zich met name op de professionele gebruikers, ingegeven door de vaststelling, dat in de afgelopen decennia de betrokkenheid van professionele beleggers en analisten op de kapitaalmarkt zeer sterk is toegenomen, ten koste van het aandeel van de niet-professionele spelers op deze markt.

12 Zie Craig (1994), warin Robert Elliott, lid van het Jenkins Commirtee stelt: "The range [of the preparer community's reactions] is from skeptical to hostile. (...) They are concerned with competirive costs. For example, U.S. preparers resent that they have a higher level of disclosure than do overseas companies with which they compete.' 
* Het belang van dit aspect wordt onderstreept door cen studie van Bryan (1997), waarin een positieve correlatie werd gevonden tussen opmerkingen in de Management Discussion and Analysis (onderdeel van de jaarlijkse rapportageset, vereist door de SEC) en ontwikkelingen in bepaalde kengetallen in het jaar erna (onder meer winst per aandeel).

4. Van de respondenten vindt $57 \%$ dat de accountant een oordeel moet geven over de betrouwbaarheid van de opgenomen prospectieve informatie, terwiil $52 \%$ vindt dat de accountant ook een oordeel moet geven over de nier-financiële informatie. Wel vindt een grote meerderheid, dat de betrokkenheid van accountants bij de (toetsing van de) internal accounting controls vergroot dient te worden. Voorts wordt van de accountant meer commentaar verwacht op zaken als alternatieve waarderingsgrondslagen, redelijkheid van aannames van het management en risico's ten aanzien van de terugverdiencapaciteit van activa.

"Als tijdshorizon wordt in de taakstelling een periode van 5 tot io jaar genoend. Zie voor vergelijkbare analyses ICAEW (1996) en CrCA (1996).

${ }_{16}$ Ter vergelijking luidt de definitie van attestation services: 'An engagement in which a practitioner is engagaged to issue, or does issue, a written communication that expresses a conclusion about the reliabillity of a written assertion that is the responsibility of another party' (AICPA, 1993). Het resultaat wan cen attestation engagement (waaronder begrepen de traditionele 'audit') is een schriftelijke conclusie over de betrouwbaarheid van een bewering van een derde, terwijl het resultaat van een assurance-opdracht bestaat uit betere informatie voor een beslisser, met mogelijk als bijproduct aanbevelingen (AICPA, 1996).

7 Het betreft: (x) Information systems reliability, zijnde assurance dat systemen zodanig zijn ontworpen en benut, dat betrouwbare informatie wordt gegeneteerd; (2) Electronic commerce, waarmee wordt beoogd om zekerheid te verschaffen ten aanzien van de integriteit, veiligheid en privacy van electronische transacties (Elliot \& Pallais, 1997d; Koreto, 1997); (3) Health care performance measurement, zijnde assurance over de prestaties van dienstverleners in de gezondheidszorg; (4) ElderCare-Plus, zijnde assurance gegeven aan ouderen of bun familieleden over de prestaties (en de honorering) van dienstyerleners in de ouderenzorg (Elliott \& $\mathbb{P}$ allais, 1997a); (s) Risk assessment, zijnde assurance over de idencificatie van business risks, de classificatie ervan in termen van kans en potentiele impact alsmede de kwaliteit wan de afdekking door controls (Elliot \& Pallais, 1997c); en (6) Business performance measurement, waarbij assurance word verleend ower de relevantie en/of de betrouwbaarheid van prestatiemaatstaven (Elliott \& Pallais, 1997b). 
18 In Elhort (1995; 1997) worden met name onderzoekswragen ower de vraag- en de technologiezijde gesuggereerd.

19 Binnen het raamwerk van deze Exposure Draft vallen opdrachten waarbij een professionele accountant een conclusic verwoordt ower een onderwerp waarvoor en ander de verantwoordelijkheid draagt, door dit onderwerp te toetsen aan de hand van gë̈dentificeerde, deugdelijke criteria. Uit de meest recente versie van deze Exposure Draft (IFAC, 1998) blijkt, dat IFAC - in navolging van het Elliott Committe - de kwaliteitsdimensies relevantie en betrouwbaarheid binnen het werkgebied wat.

2.5 Door een aantal grote accountantsfirma's worden in hun meest recente controle-aanpakken reeds elementen van business risk assessment gehanteerd. Zie bijwoorbeeld Bindenga (1998), Ten Wolde (1998) en Dassen \& Coster (1998).

20 Touw (1994) definieert 'compliance' alss 'het geheel van maatregelen gericht op de handhaving van relevante gedragsregels?.

2.2 Deze algemene vragen zijn voor een deel gebaseerd op vraagstellingen in de reeds besproken rapporten wan het Elliotr Committee (AICPA, 1997), de IFAC Exposure Draft 'Reporting on the Credibility of Information' (IFAC, 1997), alsmede op een paper van Carcello, Messier \& Ricchiure (1998), voortkomend uit de Task Force on Future Audit, Attestation, and Assurance Services van de Audic Section van de American Accounting Association.

${ }^{29}$ Geduid wordt op de aanbevelingen van het Jenkins Committee, waarvan Elliott eveneens lid is geweest.

24 Fargher \& Gramling (1996) rapporteren, dat "investment managers" op vrijwillige basis rapportages over hun beleggingsperformance laten toetsen door een assurance provider, om op die wijze geloofwaardigheid toe te voegen aan die rapportages, een perceptie die - naar blijkt uit nader onderzoek - inderdaad wordt gedeeld door de gebruikers van deze prestatiemaatstaven.

wh Fargher, Gorman \&C Wilkins (1998) onderzochten de reactie van de aandelenmarke op publicatie van de mandelijks door Price Waterhouse Llp samengestelde en op redelijkheid getoetste book-to-bill cijfers (ratio nieuw ontvangen orders wersus verkopen) wan de halfgeleidersindustrie.

${ }^{26}$ Zié ook de korte bespiegeling hierover in het Hoofdstuk "Toetsingscriteria en technologic. 
27 Zie ook Maisel (I992): All too often, fruancial measures are excessive and overburden managers with information that does not enable them to deternine the adequacy of their strategies and actions. This was best characterized by the executive who said: "When I receive the financial reports, I'm either happy or upset, but rarely am I smarter." :

\section{${ }^{28}$ Zie ook Groot, Van der Meer-Kooistra en Wouters (1998)}

29 Procesgerichte maatstaven hebben betrekking op handelingen en processen (kwaliteir producten; ontwikkelingstempo nieuwe producten); personele indicatoren hebben betrekking op het gedrag wan individuen en groepen: morvatie, relaties met personeel. Deze drie matstaven sluiten nauw aan bij Merchant $(1985,1997)$.

30 Blommaert (1994) vond overigens in cen experiment, dat andere informatic dan die welke woortwoeir uit dubbel boekhouden' relevant kan zijn voor beslissers. Controllers die beschikten over addirionele informatie in de vorm wan triple-entry/momentum accounting informarion kwamen in zing onderzoek tot betere voorspellingen dan controllers die niet over deze informatie beschikten.

${ }^{35}$ Met andere woorden, is, voorafgaande an toetsing door een externe assumance provider, nier-financiële informatie binnen een bedrijf even betrouwbaar als financiele informatie? Gelet op de historische facus van interne controle-systemen op financiele verslaggeving kan worden verwacht, dat de betrouwbaatheid. van niet-financielle maatstaven lager is.

32 In Nederland is dit element met name vervat in Aanbeveling 21 (Commissie Peters, 1997), waatin staat: "De Raad van Bestuur rapporteert schriftelik aan de Raad van Commissarissen over de ondernemingsdoelstellingen, de strategte, de daaraan verbonden risico's en de mechanismen tot beheersing van risico's van financiele aard. De hoofdzaken van de rapportage behoren een vaste plaats in her jaarverslag te hebben.'

33 Dit gezien de overwegend afwijzende reactic van Raden van Commissarissen van beurfondsen op aanbeveling 35 wan de Commissie Peters: 'De Raad van Commissarissen dient te bezien of de accountant de juistheid van de rapportage omrent de opvolging van verifieerbare aanbevelingen dient te onderzoeken.'

34 De accountant rapporteert, dat de uitspraken wan de Board ower internal financial control niet in strijd zijn met de informatic waarover de accountant beschikt in het kader van de controle van de jaarrekening. 
35 Vak zal deze informatie in afgeleide worm beschikbaar komen. Zo kan een onwerwachte tegenvaller in resultaten van een beursonderneming tewens worden uitgelegd als een indicatie van een tekortkoming in het systeem van interne beheersing. In zijn algemeenheid is het interessant om een verkennend onderzoek te doen naar de vormen van publiekelijk beschikbare rapportages over of indicaties van de kwaliteit van interne beheersingssystemen.

${ }^{36}$ Brackney \& Helms (1996) deden onderzoek maar de rypen arrestation services die in de Verenigde Staten regelmarig worden uitgevoerd. $\mathrm{Zij}$ vonden, dat de niet-financiele attestation services relatief sterk ondervertegenwoordigd waren, hetgeen erop zou duiden, dat accountants en/ of hun opdrachtgevers toch geneigd om de dienstverlening vooral in de traditionele fnanciële hoek te zoeken.

37 See \& Mock (1998) hebben onderzoek uitgevoerd naar de belangstelling van partners en managers van de Big 6 kantoren in Singapore naar de potentiele assurance services die zijn voorgesteld door het Elliott Committee. Van de zes door Elliott specifiek uitgewerkte diensten ziet men risicomanagement, prestariemeting, betrouwbaarheid van informatiesystemen services, en "electronic commerce als interessante werkterreinen. Ook van de overige door Elliort gesuggereerde diensten wordt een aantal als interessant aangemerkt, daaronder begrepen "continuous audit", milieu-audits, onderzoek naar prospectieve informatie en toetsing van het interne beheersingssysteem.

${ }^{38}$ Dassen en Schelleman (1998) hebben in Nederland aan zes partners, verantwoordelikk voor vaktechnick audit services bij de Nederlandse Big 6 firms, gevraagd naar hun inschatring van het potenticel van assurance services. De bevindingen uit dit onderzoek zullen per categorie assurance services in de telkst worden besproken. Voorts loope in het kader van deze paper een enquête onder praktiserende accountants naar hun inschatting van de mogelijkheden van assurance services in Nederland.

39. Deze bevindingen stroken in grote lijnen mer de bevindingen van Brackney $\&$ Helms (1998) aangaande de hindernissen om attestation services in de toekomst uit te breiden.

4o Schloemer and Schloemer (1997) vonden geen significant verschil in her percentage "incuition" types tussen consultants, belastingadviseurs en accountants binnen Big 6 en andere kantoren.

4: Zie onder meer Kinney (1999).

"Zi Zie onder meer Applegate, Mclarlan \& McKenney (1996). 
43ie onder meer Vaassen (1998).

44 King and Schwartz (r998) wijzen deze zorg overigens van de hand, door op grond wan een mathematisch model aan te tonen, dat consumenten moch producenten van assurance services belang hebben bij kwalitarief laagwaardige assurance services.

45 Voor een overzicht van theoretische en empirische studies op dir gebied, zie onder meer Schillder (1992) en Dassen (1995).

46 Voorts leidt toepassing van her joint-supply-scenario (Simunic, 1984; Palmrose, 1986; Davis et al., 1993) op assurance services tot de hypothese dat de synergie tussen assurance en audit bij een cliënt ertoe zal leiden dat de audit goedkoper wordt en daarmee wellicht meer auditwerkzaamheden gevraagd zullen worden, hetgeen een posirief effect op de kwaliteit van de jaarrekeningcontrole zou hebben.

47 Dit blijkt overigens ook al uit het gebrek aan consistentie in de bevindingen uit empirisch onderzoek op dit wlak, zie andermaal Schilder (r992) en Dassen (1995).

4 Het onderzoek had betrekking op de pension plan audit markt, waarin de assurance-rol van de accountant in de VS aanzienlijk verder gaat dan de reguliere controle van de jaarrekening.

9 Andere aanbieders van deze dienstverlening in de Amerikaanse markt zijn onder meer Certified Financial Analysts.

50 Zie hiertoe ook de opmerkingen dienaangaande in het Hoofdstuk "Toetsingscriteria en technologié.

51 Zie Richtlijn 81o (Koninklijk NIvRA, 1998), waarin onder par. 27A staat: 'In Nederland bevat het rapport inzake een onderzoek van toekomstgerichte informatie de vermelding dat een dergelijk onderzoek in hoofdzaak is bepertkt tot het inwinnen wan inlichtingen, her uirvoeren van cijferanalyses en het vastestellen dat de veronderstellingen op de juiste wijze zijn verwerkt.'

$5^{2}$ De criteria kunnen worden onderverdeeld in gebruikers-, applicatic- en projectmanagement-gerelateerde criteria.

${ }_{3}$ Zie ook Brecht \& Martin (1996). 
14. Zie in dit werband ook Slagter (1996), die in her kader wan "compliance audit' en antal gedragsregels beschrift die zich lenen voor toetsing op naleving door een derde. 